\title{
Har vi råd til at være kameler?
}

\section{Kompetenceløft skal skrives ind i budgetterne}

\section{Kronik af Dorthy Rasmussen}

Leder af kompetenceenheden, Københavns Universitet

Kameler er forræderiske: De går tusindvis og atter tusindvis af skridt uden at vise tegn på træthed. Men pludselig knæler de ned og dør. Heste derimod bliver trætte lidt efter lidt. Og du ved altid hvor meget du kan forlange af dem eller hvornår de vil dø.

Kompleksitet er ikke kun et buzzword, men et vilkår i det enogtyvende århundrede.

Ser du kun én nuance, kan du kun ét argument og kender du kun én løsning, løber du hurtigt tør. Det gælder, hvad enten du er direktør, skolelærer, politiker eller pædagog.

Interaktioner og relationer, tilfældigheder og ukontrollerede påvirkninger gør vores virkelighed mangesidig og sammensat. Årsags-virkningssammenhænge er ikke lineære, men består af en mangfoldighed af problemer og løsninger. Tidligere efterstræbte ligevægte er blevet uinteressante tilstande der blokerer for kreativ fornyelse. I stedet skal vi nu på kanten af kaos evne at rekonstruere hidtidige erfaringer på måder der muliggør dannelse og realisering af nye idéer på tværs af landegrænser og kulturer.

Vi skal være rede til fornyelse, nye udfordringer, nye vinkler på udfordringer der forekom løste og afklarede. Fremtidens danskere har gennem folkeskole over gymnasier til efteruddannelser brug for konstant påfyldning, så vi er maksimalt klædt på til foranderlige og fornyende opgaver.

Vi skal være heste, parate til givende pauser, og ikke bare kameler, i det lange løb som arbejdslivet udgør.

Arbejdsliv og identitet smelter sammen - på en måde der angår alle. Ambitionerne rækker videre end til et jævnt og muntert virksomt liv. Vi ønsker at opfylde vores egne historier og drømme. Arbejdet er blevet et område for personlig udvikling ligesom de enkelte mennesker er blevet afgørende for organisationernes udvikling. En gang indlærte procedurer er ikke nok. Det er ikke længere tilstrækkeligt at udfylde rammen, vi skal sætte nye standarder.

For at have overskud på kompetencebalancen gennem hele livet har vi brug for at få blæst støv af hjernen, for åndehuller og oaser, for luftspejlinger og refleksioner.

Vi udvikler os dagligt - i mødet med andre og i alle livets læringssituationer, formelle som uformelle. Afgørende for effekten er at vores viden og erfaringer jævnligt udfordres og perspektiveres.

Viden, holdninger og følelser er stærke kort, som kan give Danmark muligheder for fortsat at spille med på højeste niveau på verdensscenen.

Strukturelt betragtet er efter- og videreuddannelse en bæredygtig investering der bidrager positivt på alle niveauer: vækst og demokrati styrkes i samfundet, bundlinier forbedres i virksomheder og organisationer, og et fuldt og rigt liv udfoldes for det enkelte individ. Det er dog ikke ligegyldigt hvilke uddannelser vi vælger. Udbudet er af svingende karakter og man kan let gå forkert, spilde sin tid eller ikke få kvalitet nok. 
Universiteterne er i springfart på vej til at blande sig med et kvalitativt indspil til efter- og videreuddannelse. Ofte i tværgående fag der nyttiggør viden og erfaringer fra arbejdslivet. Igennem de seneste år er der på alle hovedområder udviklet og igangsat en bred vifte af aktiviteter, fra kurser af 1-2 dages varighed til toårige masterprogrammer. Fælles for dem er at undervisningen foretages af forskere der dagligt arbejder med at skabe og udveksle ny viden.

Universiteternes vigtigste bidrag til videnformidling har været og er fortsat vores mange kandidater.

Men vi har meget mere at byde på. Både når det gælder formaliseret efter- og videreuddannelse og når det gælder udviklende netværk og samarbejdsaftaler med virksomheder, organisationer og institutioner.

Både som universitetets fødekæde og som en del af den uddannelsespolitiske debat er folkeskolen og gymnasierne vigtige og aktuelle emner. Som universitet har vi en direkte interesse i debatten om lærerkompetencer og er derfor også parate til at bidrage i udviklingen af det samlede uddannelsessystem fra folkeskole til professionsbacheloruddannelser. Gymnasiereformen har været en god anledning til at intensivere relationerne til ungdomsuddannelserne. I 2005 indgik Københavns Universitet som led i en gymnasiesatsning i over 50 nye efter- og videreuddannelsesaktiviteter til underviserne.

\section{Finansiering}

Men er den tilbudte ramme for efter- og videreuddannelse så tidssvarende? Jeg mener nej. Spørgsmål om finansiering og anerkendelse har ikke fundet sine endelige svar.

Politisk har fokus siden 2000 ligget på at stimulere udbudssiden, dels gennem udviklingsmidler til nye uddannelsestilbud, dels gennem lovændringer. Effekten heraf har været positiv på den måde at der er igangsat et stort antal efter- og videreuddannelsesaktiviteter. Universitetet skal imidlertid have dækket sine omkostninger, og udgifterne væltes derfor over på deltagerne. Og kvalitet koster.

På efterspørgselssiden halter erkendelsen af dette dog bagefter.

Hvor arbejdsgiverne har været vant til at belønne deres stjernemedarbejdere med efter- og videreuddannelse, er der nu tale om et behov for en bredere forståelse af kompetenceudvikling.

Når værdiskabelsen flytter fra maskiner til mennesker, bør brændstof og afskrivninger naturligt følge efter. Mange arbejdsgivere har en god forståelse af dette, men desværre har langt fra alle det tilsvarende økonomiske råderum til at finansiere et stort udbud af mere eller mindre skræddersyede tilbud.

Finansieringsnøglen ligger i en balancering mellem tid, penge og anerkendelse. Tid til deltagelse, tid til forberedelse. Penge til deltagerbetaling og bøger, penge til vikardækning. Anerkendelse som avancement, som løn, som udvidet jobindhold, som nye organiseringsmuligheder. Der findes ikke et entydigt svar på, hvordan fordelingsforholdet mellem tid, penge og anerkendelse fastsættes. Arbejdsmarkedets forskellige brancher og faggrupper kræver hvert sit tilpassede snit.

I nogle brancher er der tradition for at arbejdsgiveren finansierer dyre efter- og videreuddannelsesprogrammer mod at arbejdstager til gengæld investerer sin fritid i deltagelsen. Denne model finder sin berettigelse i tanken om at uddannelsen bidrager til virksomhedens udvikling og vækst, men også til medarbejderens udvikling og vækst udtrykt i employability.

I undervisningssektorer har der været tradition for at arbejdsgiveren finansierer både deltagerbetaling, timer og evt. vikardækning. Til gengæld har kurserne været korte og billige. 
Som et eksempel fra vores arbejde præsenterede en studieleder for nylig et tværfagligt, kursusforløb i Verdenssyn på et møde i et inspirationspanel for gymnasiesektoren. Kurset blev meget positivt modtaget i gruppen, men prisen på kr. 4.500,- var bestemt ikke populær. En vicerektor henviste til at hendes arbejdsplads var vant til at bevilge fra kr. $150-750$ for kurser. Studieleder oplyste ulykkeligt at universitetet ikke tjente en krone på at gennemføre kurset. Pilotprojektets økonomi løb kun lige akkurat rundt ved hjælp af Undervisningsministeriets medfinansiering.

Endelig også et par ord om den tredje dimension, anerkendelsen. Hvis deltageren ved at der ligger en lønforhøjelse og venter efter gennemførelse af efter- og videreuddannelsesaktiviteter er villigheden til selv at medfinansiere både tid og penge naturligvis større. Det er imidlertid stadig få arbejdspladser hvor der er etableret direkte sammenhæng mellem efter- og videreuddannelse og anerkendelse.

I efteråret 2005 fik Københavns Universitets Kompetenceenhed gennemført en eksplorativ undersøgelse af hvilken effekt en masteruddannelse har for deltagerne. To fokusgruppeinterviews med masterkandidater $1 \frac{1 / 2}{2}$ år efter de havde afsluttet deres uddannelse viste blandede resultater. Alle var stolte og glade for at de havde gennemført uddannelsen. Flere gav imidlertid udtryk for at deres arbejdsplads ikke havde været parat eller i stand til at tilbyde et udvidet jobindhold der matchede deres nye kompetencer. Relationerne til deres arbejdskolleger var også forrykket på en uhensigtsmæssig måde: kolleger med en kandidatuddannelse tilbød ikke optagelse i deres arbejdsfællesskab, mens kolleger med en professionsbachelor følte sig distanceret af masterkandidatens akademisering. Også i privatlivet var der tegn på at masteruddannelse havde medført en opstigning i et socialt tomrum.

Ferielov og pensionsopsparing har vi danskere haft i årtier nu. Er det ikke på tide med en lignende fast konto for efter- og videreuddannelse? Det vedvarende kompetenceløft skal skrives ind i budgetterne - og være med til at holde os fleksible. Vi skal være fleksible og smarte som heste, ikke bare udholdende som kameler.

Lœs mere om Kompetenceenhedens arbejde og undersøgelser på www.ku.dk/kompetence. 